\title{
Social participation of city inhabitants versus their future orientation. Evidence from Poland
}

\author{
DANUTA SZPILKO, JOANNA SZYDŁO, JUSTYNA WINKOWSKA
}

\author{
Faculty of Engineering Management \\ Bialystok University of Technology \\ 45A Wiejska Street, Bialystok 15-351 \\ POLAND
}

\begin{abstract}
Social participation in contemporary concepts of city management plays an important role in the process of building future-oriented city development strategies based on co-creation, cooperation and co- management. The aim of the article is to define the scope of social participation of the inhabitants and their future orientation in the context of shaping urban development in Poland. The article presents the results of research conducted among 516 Polish inhabitants. In the study, methods of literature analysis and diagnostic survey (CAWI technique) were used. The results of the research are an attempt to integrate social participation and future orientation. They can be useful for city decision-makers who see the need for wider social involvement in the process of shaping cities' future. The results provide information to what extent and with what tools of social participation it is possible to effectively involve future-oriented stakeholders. At the same time, the results indicate what should be the participation of individual social groups in the city development process so that it is socialised. The obtained results may serve as an important determinant for city authorities in the process of strategic management of city development based on social participation.
\end{abstract}

Key-Words: city, social participation, future orientation, strategy management

Acknowledgment: This research is supported by Bialystok University of Technology and financed from a subsidy provided by the Minister of Science and Higher Education.

Received: February 4, 2020. Revised: June 29, 2020. Accepted: July 10, 2020. Published: July 24, 2020.

\section{Introduction}

Cities are the future of the world. The 21 st century will not be dominated by countries as such, but by cities. In the modern world, these are not states, but cities that are the centres of government on which the future world order will be built [1]. The city is characterised by the complexity of many links between elements that become integrated into a wellfunctioning and developed entity [2]. The city, and above all its inhabitants, usually has a much greater impact on the social and economic life of a given country than an apparent potential related to the population since it accumulates the characteristics of a given community [3]. As the global population of cities increases, there is a growing demand for new, innovative ways of managing complex city life. In the last decade, social participation has become very popular in the context of shaping city development and strategic management. With an appropriate focus on the future, social participation fosters development activities to better meet the current and future needs of inhabitants.

The aim of the article is to define the scope of social participation of the inhabitants and their future orientation in the context of shaping urban development in Poland. The results obtained will provide information to city decision-makers to overcome the difficulties and challenges of social participation in the context of city development. The analysis will focus on providing information to what extent and with what participatory tools it is possible to effectively involve future-oriented stakeholders. It will also be indicated what should be the participation of particular social groups in the process of city development so that each of them can indicate their needs.

With regard to the aim of the article the authors formulated 3 research hypotheses:

H1: The higher the level of inhabitants' future orientation, the greater their social involvement. 
H2: Effective tools of social participation according to highly future-oriented inhabitants that foster a real impact on city development are: involvement of inhabitants in the implementation of specific projects, joint strategy development and its joint implementation.

H3: The current participation of inhabitants and scientists in shaping the city's development is too small in relation to the participation of city authorities and politicians.

\section{Literature review}

The aim of each territorial unit that constitutes a local social system is development. In the process of local development, participation and social communication gain special importance [4]. The issue of participation started to be emphasised in the scientific debate and planning activities in the 1960s [5-8]. Participation should be understood as not only the possibility of social consultations, but first of all, the involvement of citizens in activities which, through inclusiveness and diversity of views, allow for reaching consensus. Social and economic changes taking place at all levels of local government are an inherent element of such an approach [9]. The mentioned consensus building, according to McCann, is the key objective of participatory practices which foster the involvement of all the city's "users", and not only those who believe that they have a greater impact on the results because they have the right to control the future urban landscape [10]. This involves using various forms of cooperation between local authorities and citizens to better adapt public services to the needs reported by inhabitants [11-17]. Moreover, social participation is a form of educating society, it enables the inclusion of social values and preferences into the decisionmaking process, while improving the quality of decisions (in terms of their content and cost), and contributes to increasing trust in the authorities as well as reducing conflicts [18]. Callahan [19] indicates that the involvement of citizens in the decision-making process is a good idea.

There are many ways to consult the public, but there is still a gap in terms of how citizens can be involved in the decision-making process. So far, there is clearly no best way to achieve meaningful citizen involvement. The co-decision process can be implemented with the use of different participatory tools, depending on the level of participation. At the lowest level, leaflets, websites, exhibitions, open houses or participatory innovation platforms are used for information purposes [20-23]. In order to obtain feedback from the public, surveys, public comments, public meetings, focus groups can be used. The forms in which citizens have the possibility of exerting a direct influence include: advisory committees, participatory decision-making (budgets), citizens' juries etc. [24,25]. Litvack and Seddon pointed out that local referenda, regular public-private meetings and other institutional structures can contribute to improving the ability of local governments to recognise and act towards the preferences of their citizens [26].

Social participation can involve a very wide range of activities focused on different stakeholders [2729], i.e. inhabitants, enterprises or NGOs, and their roles (e.g. as advisory councils for social affairs or development, in planning, supporting city management, or by participating in public decisions) [30]. The socialisation of power acquires new content in the smart city, in which human and social capital play a key role [31-36].

In city management, the focus should be placed on understanding the possible paths of city development and choosing those which are sustainable and durable, in accordance with the prospective and shared vision of the city. A solid knowledge base as such is insufficient to create a long-term vision to guide activities. Cities must also have adequate tools for strategic planning and collective participatory vision building [37]. In order to involve citizens, practitioners should be clear about their intention to convene citizen meetings and project their engagement in a way that provides a clear path from involvement to satisfaction. It is important to design participation in such a manner that its results are relevant to the participants [38]. Therefore, these measures should involve active stakeholders.

Societies should be aware of the need for immediate action and full involvement of all stakeholders in the process of co-determination and co-creation of cities. Kjaer [39] emphasises that the future is not the place we are aiming at, it is the place we are creating. Future orientation should therefore accompany all people both in their future and in the future of their cities.

Future-orientation in scientific literature is divided into two different approaches: psychology of personal development [40-42] and futures research $[43,44]$. Future orientation is closely linked to development. By setting goals for the future, both personal and social development can be designed [45]. It fosters movement in a broad time perspective and looking to the future while developing plans, predicting consequences and developing hypothetical projects $[46,47]$. Future orientation in the city context can be perceived as a group of futureoriented inhabitants involved in strategic city 
management. Future orientation in the context of city development involves the use of a whole range of methods used in futures research [48] and is strongly linked to such concepts as strategic foresight and strategic intelligence [44,49].

So far in literature, researchers have focused exclusively on exploring the phenomenon of social participation. The approach proposed by the authors, i.e. the direction of social participation in the aspect of the future, is poorly described in the literature, as the analysis shows. However, in the context of city development, there was no empirical research in this area. This article is an attempt to combine social participation with future orientation in the context of city development.

\section{Research methods}

The research involved a diagnostic survey based on the CAWI technique. It covered the area of Poland and was conducted in the period from $17^{\text {th }}$ September 2018 to $30^{\text {th }}$ November 2019. The authors obtained a total of 516 correctly completed questionnaires. The obtained data from all questionnaires were subjected to the statistical analysis with the use of Statistica 13.3 software.

The survey involved a representative group of respondents consisting of 292 women $(56.6 \%)$ and 224 men (43.4\%). $24.8 \%$ of the surveyed represented the group of 18 -24-year-olds, $30.2 \%$ - 25-34-yearolds, $24.0 \%$ were at the age of $35-44,16.5 \%-45-55$, and $4.5 \%$ represented a group above 55 years of age. The respondents lived in cities of various sizes: over 250,000 inhabitants (55.6\%), under 20,000 inhabitants (16.1\%), 21-50,000 inhabitants (12.6\%), $51-150,000$ inhabitants (5.6\%), 151-250,000 inhabitants (5.6\%).

The respondents were asked about their future orientation with regard to 13 statements that included both short- and long-term planning issues. They made a self-assessment of their future orientation on a 7-point Likert scale. Figure 1 presents averages obtained for each statement. The average of all 13 statements oscillated between 4.09.

On the basis of the averages for future-oriented planning, 3 categories of respondents were selected: highly future-oriented (average 4.68-7), medium future-oriented (average 2.34-4.67), low futureoriented (average below 2.34). The most numerous group was composed of respondents with medium future orientation $-56.2 \%$. Highly oriented towards future planning constituted $32.8 \%$ of respondents, while those with low orientation $-11.0 \%$ (Table 1 ).

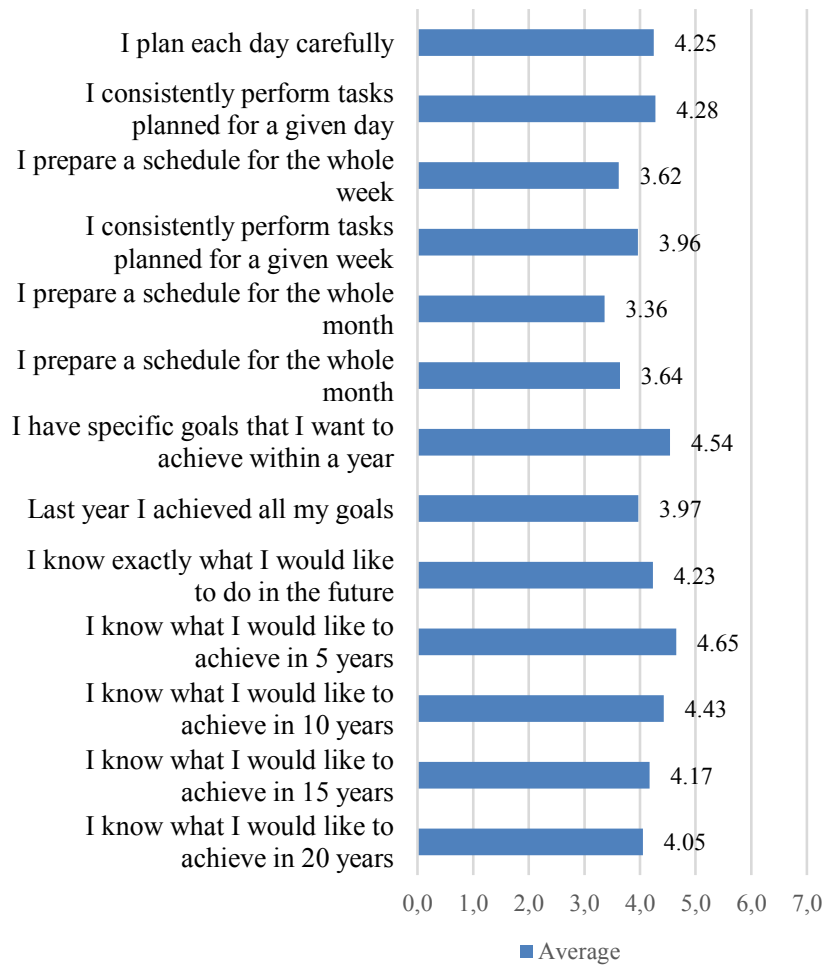

Figure 1. Future orientation of respondents

Source: authors' own research.

Table 1. Respondent categorisation in terms of their future orientation

\begin{tabular}{|c|c|c|}
\hline Level of future-orientation & Number & Percentage \\
\hline Highly future-oriented & 169 & 32.8 \\
\hline Medium future-oriented & 290 & 56.2 \\
\hline Low future-oriented & 57 & 11.0 \\
\hline
\end{tabular}

Source: authors' own research.

\section{Research results}

The research shows that $70.3 \%$ of the respondents are interested in the issues of their city, where a high percentage of $78.1 \%$ of them feel emotionally attached to it. $46.9 \%$ of the respondents are convinced about the possibility of their real influence on their city's affairs, while only $28.7 \%$ try to be active in this matter (Figure 2). 


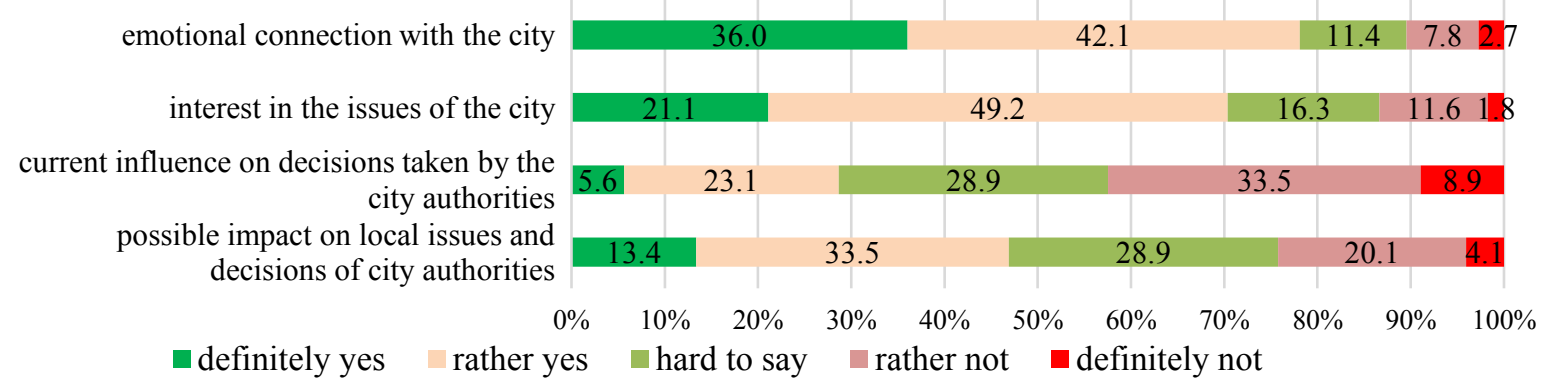

Figure 2. Inhabitants' engagement in city development

Source: authors' own research.

The attitude of city authorities towards the initiatives of inhabitants is assessed at a high level by only $0.2 \%$ of the respondents and at a good level - by $40.6 \%$ of respondents. Average ratings are given by $32.0 \%$ of respondents, and bad or very bad - by $4.8 \%$. $17.6 \%$ of the respondents did not express any opinion in that matter.

\subsection{Social participation of city inhabitants}

Among the respondents, $70 \%$ were involved in one social activity at least once. Among the most frequently indicated were: signing petitions $(70.0 \%)$, participation in local government elections $(65.3 \%)$, voluntary work $(62.0 \%)$, assistance in organising a local event $(59.1 \%)$. It should be noted that the indicated activities were mainly undertaken 2-3 times or more. The least frequently indicated social activities of the respondents include: participation in the development of city strategy (14.7\%) and participation in meetings with councillors concerning the directions of city development $(24.0 \%)$. It should be emphasised that $16.3 \%$ of the respondents, in the context of their participation in the preparation of a city development strategy, indicate their intention to become involved in that activity in the future. This means that city inhabitants are aware of the need to get involved in shaping the development of their cities and to co-decide about their future. The social involvement of various groups of stakeholders in the development of strategic documents allows for building a vision of the city consistent with the various needs of its inhabitants. Figure 3 illustrates a detailed breakdown of responses.

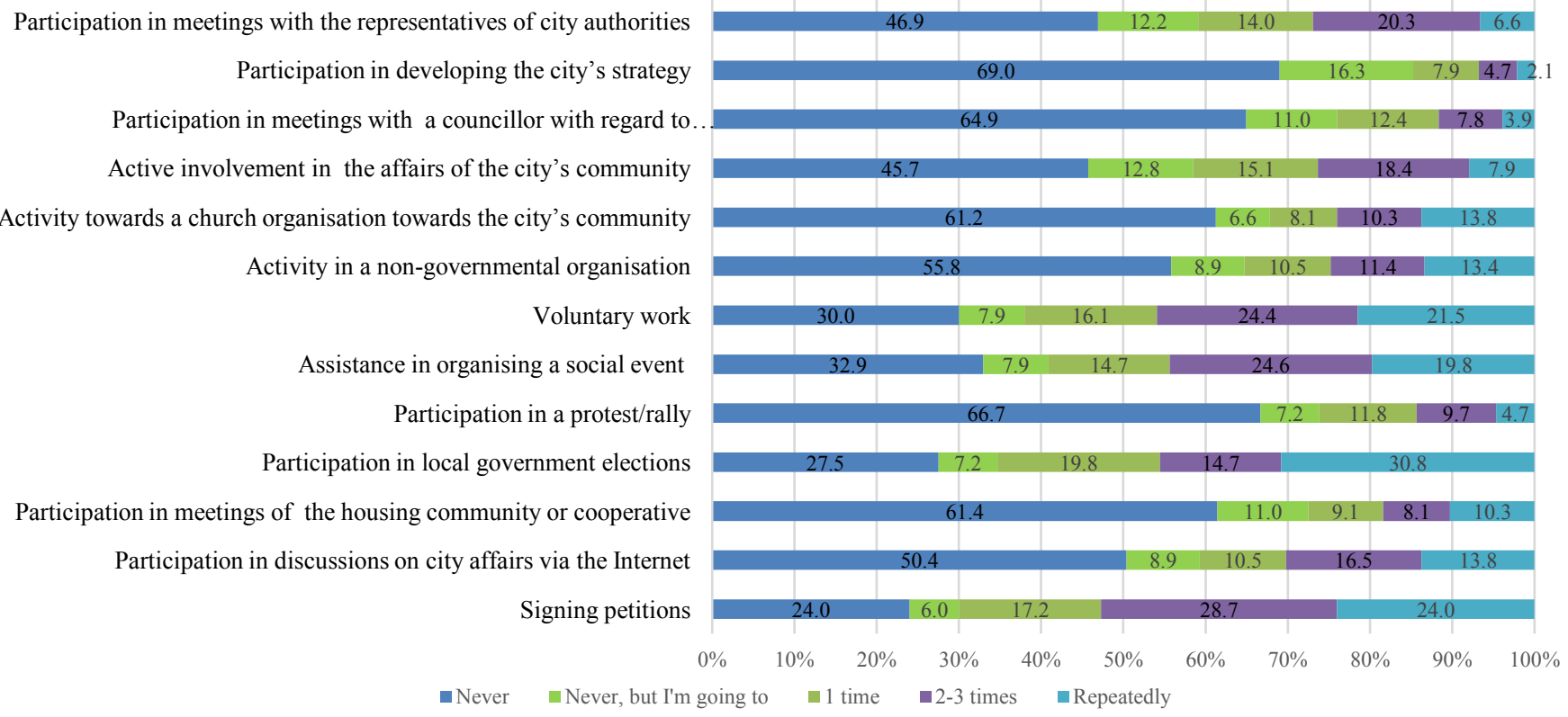

Figure 3. Forms of social participation of inhabitants in city development

Source: authors' own research. 
In analysing the results obtained by groups of inhabitants with regard to their level of future orientation it should be noted that the level of social involvement in individual groups varies. Highly future-oriented inhabitants are mainly involved in a number of social activities: signing petitions (72.5\%), voluntary work $(71.6 \%)$, assistance in organising a local event $(69.2 \%)$, participation in local government elections $(68.0 \%)$, active involvement in the affairs of the city's community (47.9\%), participation in meetings with the representatives of city authorities $(47.3 \%)$, participation in discussions on city affairs via the Internet $(45.6 \%)$, activity in a non-governmental organisation (44.4\%). Mediumoriented inhabitants are mainly involved in: signing petitions $(67.0 \%)$, participation in local government elections $(65.5 \%)$, voluntary work $(60.3 \%)$, assistance in organising a local event (57.2\%), participation in meetings with the representatives of city authorities $(41.4 \%)$, participation in discussions on city affairs via the Internet $(41.4 \%)$, active involvement in the affairs of the city's community $(40.3 \%)$. Inhabitants with low future orientation are mainly engaged in: signing petitions $(66.7 \%)$, participation in local government elections $(56.1 \%)$, voluntary work (42.1\%). Table 2 presents a detailed breakdown of the results.

In the course of further analysis, the Chi-Square test of independence was carried out to determine whether there is a correlation between the type of social activity and the level of future orientation. Statistically significant differences $(p<0.05)$ were obtained in relation to the following activities: participation in meetings with the representatives of city authorities $(p=0.001)$, active involvement in the affairs of the city's community ( $\mathrm{p}=0.026$ ), activity in a non-governmental organisation $(\mathrm{p}=0.001)$, voluntary work $(\mathrm{p}=0.000)$, assistance in organising a local event $(\mathrm{p}=0.000)$, participation in a protest/rally $(p=0.002)$, participation in meetings of the housing community or cooperative $(\mathrm{p}=0.004)$, participation in discussions on city affairs via the Internet $(\mathrm{p}=0.010)$, (Table 2).

Significant differences in social involvement with regard to the level of future orientation were obtained in relation to the following activities: assistance in organising a local event $\left(\chi^{2}=17.505\right)$, voluntary work $\left(\chi^{2}=16.523\right)$, activity in a non-governmental organisation $\left(\chi^{2}=14.408\right)$ and participation in meetings with the representatives of city authorities $\left(\chi^{2}=13.929\right)$, (Table 2). It should be noted that these activities require devoting many more hours than, for example, signing petitions or participating in local government elections. Therefore, it may be assumed that people with high and medium future orientation are able to devote more time to social activities aimed at shaping city development than people with low future orientation. Nevertheless, in order to prove this, additional research would be needed.

Table 2. Social participation vs. inhabitants' future orientation

\begin{tabular}{|c|c|c|c|c|c|c|c|c|}
\hline \multirow{2}{*}{ Type of social participation } & \multicolumn{2}{|c|}{$\begin{array}{c}\text { Highly } \\
\text { future-oriented }\end{array}$} & \multicolumn{2}{|c|}{$\begin{array}{c}\text { Medium future- } \\
\text { oriented }\end{array}$} & \multicolumn{2}{|c|}{$\begin{array}{c}\text { Low } \\
\text { future-oriented }\end{array}$} & \multirow{2}{*}{$\begin{array}{c}\text { Chi- } \\
\text { Square } \\
\left(\chi^{2}\right)\end{array}$} & \multirow[b]{2}{*}{$\mathbf{p}$} \\
\hline & $\begin{array}{l}\text { Yes } \\
(\%)\end{array}$ & No $(\%)$ & $\begin{array}{l}\text { Yes } \\
(\%)\end{array}$ & $\begin{array}{l}\text { No } \\
(\%)\end{array}$ & $\begin{array}{l}\text { Yes } \\
(\%)\end{array}$ & No $(\%)$ & & \\
\hline $\begin{array}{l}\text { Participation in meetings with the representatives } \\
\text { of city authorities }\end{array}$ & 47.3 & 52.7 & 41.4 & 58.6 & 19.3 & 80.7 & 13.929 & 0.001 \\
\hline Participation in developing the city's strategy & 16.0 & 84.0 & 15.9 & 84.1 & 5.3 & 94.7 & 4.572 & 0.102 \\
\hline $\begin{array}{l}\text { Participation in meetings with a councillor with } \\
\text { regard to directions of the city's development }\end{array}$ & 27.2 & 72.8 & 24.5 & 75.5 & 12.3 & 87.7 & 5.284 & 0.071 \\
\hline $\begin{array}{l}\text { Active involvement in the affairs of the city's } \\
\text { community }\end{array}$ & 47.9 & 52.1 & 40.3 & 59.7 & 28.1 & 71.9 & 7.272 & 0.026 \\
\hline $\begin{array}{l}\text { Activity towards a church organisation towards } \\
\text { the city's community }\end{array}$ & 36.7 & 63.3 & 32.1 & 67.9 & 19.3 & 80.7 & 5.909 & 0.052 \\
\hline Activity in a non-governmental organisation & 44.4 & 55.6 & 33.4 & 66.6 & 17.5 & 82.5 & 14.408 & 0.001 \\
\hline Voluntary work & 71.6 & 28.4 & 60.3 & 39.7 & 42.1 & 57.9 & 16.523 & 0.000 \\
\hline Assistance in organising a social event & 69.2 & 30.8 & 57.2 & 42.8 & 38.6 & 61.4 & 17.505 & 0.000 \\
\hline Participation in a protest/rally & 34.3 & 65.7 & 24.1 & 75.9 & 12.3 & 87.7 & 12.122 & 0.002 \\
\hline Participation in local government elections & 68.0 & 32.0 & 65.5 & 34.5 & 56.1 & 43.9 & 2.680 & 0.262 \\
\hline $\begin{array}{l}\text { Participation in meetings of the housing } \\
\text { community or cooperative }\end{array}$ & 33.1 & 66.9 & 27.6 & 72.4 & 10.5 & 89.5 & 10.926 & 0.004 \\
\hline $\begin{array}{l}\text { Participation in discussions on city affairs via the } \\
\text { Internet }\end{array}$ & 45.6 & 53.4 & 41.4 & 58.6 & 22.8 & 77.2 & 9.272 & 0.010 \\
\hline Signing petitions & 72.8 & 27.2 & 67.0 & 33.0 & 66.7 & 33.3 & 1.071 & 0.585 \\
\hline
\end{tabular}

Note: Chi-square - test value, p-test probability

Source: authors' own research. 
The results of the analysis confirmed the first hypothesis: the higher the level of inhabitants' future orientation, the greater their social involvement. Highly future-oriented and medium future-oriented inhabitants are more frequently engaged in activities associated with social participation in the cities than persons with low future orientation.

\subsection{Tools of social participation}

According to the respondents, the tools of social participation facilitating a real impact on shaping the city's development include: the possibility of submitting own ideas (76.6\%), joint strategy implementation (74.8\%), joint strategy development $(74.2 \%)$, involvement of inhabitants in the implementation of specific projects $(72.7 \%)$, participation in submitting budget projects $(72.1 \%)$. It should be emphasised that the highest rated tools are related to the possibility of active social involvement and not only communication and consultation issues which include direct meetings with city authorities (59.5\%), participation in inhabitants' open meetings $(68.4 \%)$ or other various forms of Internet communication (68.6\%). A detailed breakdown of respondents' answers is presented in the Figure 4.

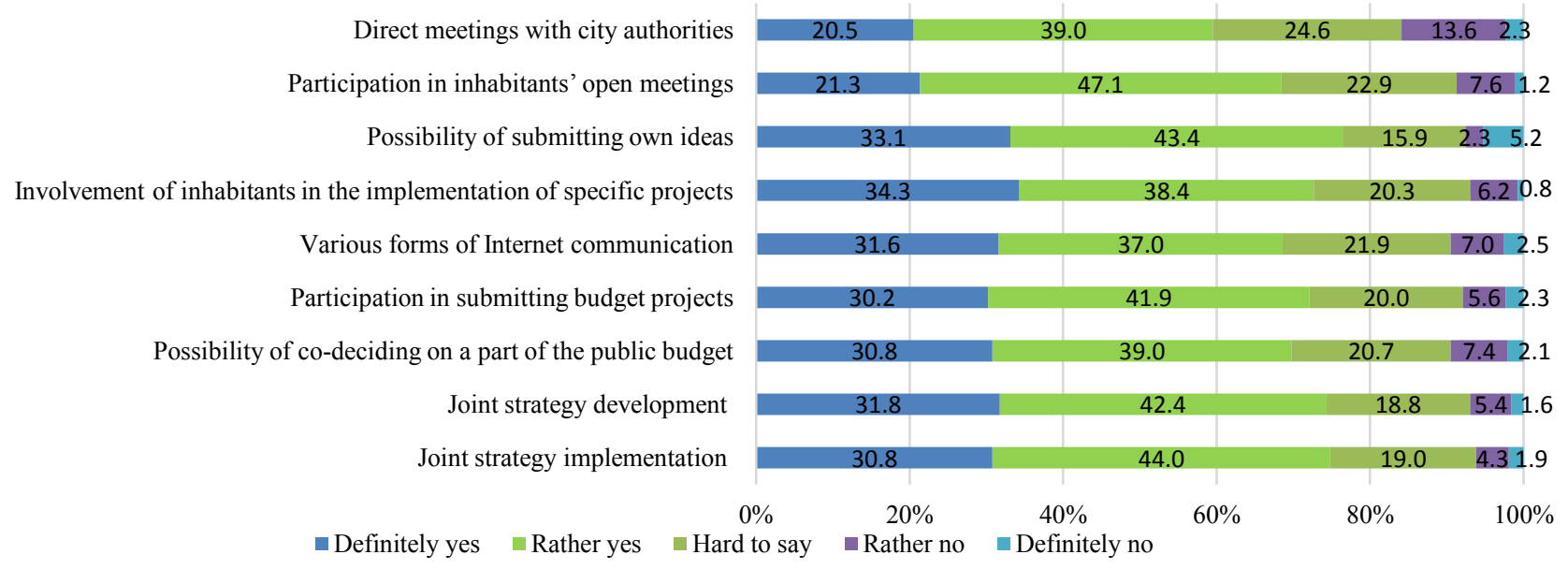

Figure 4. Tools of social participation facilitating a real impact on shaping the city's development

Source: authors' own research.

Table 3. Participation tools vs. inhabitant's future orientation

\begin{tabular}{|c|c|c|c|c|c|c|c|c|c|c|c|c|c|c|c|}
\hline & \multicolumn{4}{|c|}{ Highly future-oriented } & \multicolumn{4}{|c|}{ Medium future-oriented } & \multicolumn{4}{|c|}{ Low future-oriented } & \multirow[b]{2}{*}{ 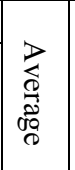 } & \multirow[b]{2}{*}{ H } & \multirow[b]{2}{*}{$\mathbf{p}$} \\
\hline & $\frac{\overleftrightarrow{d}}{\stackrel{a}{a}}$ & 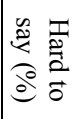 & $\stackrel{z}{a}$ & 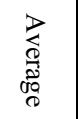 & $\frac{\overleftrightarrow{8}}{d_{0}^{0}}$ & 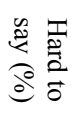 & $\frac{z}{0} \overbrace{0}^{0}$ & 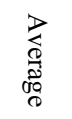 & $\frac{\sqrt{\infty}}{b_{0}^{0}}$ & 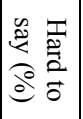 & $\frac{z}{o}$ & 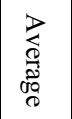 & & & \\
\hline Direct meetings with city authorities & 64.5 & 19.5 & 16.0 & 3.71 & 57.6 & 26.6 & 5.9 & 58 & 54.4 & 29.8 & 15.8 & 3.53 & 3.62 & 3.039 & 0.219 \\
\hline $\begin{array}{l}\text { Participation in inhabitants' open } \\
\text { meetings }\end{array}$ & 74.6 & 17.2 & 8.3 & 3.93 & 67.2 & 23.8 & 9.0 & 3.75 & 56.1 & 35.1 & 8.8 & 3.65 & 3.80 & 8.421 & $0.015^{*}$ \\
\hline Possibility of submitting own ideas & 79.9 & 11.2 & 8.9 & 4.11 & 76.9 & 16.6 & 6.6 & 3.99 & 64.9 & 26.3 & 8.8 & 3.74 & 3.97 & 10.492 & 0.005 \\
\hline $\begin{array}{l}\text { Involvement of inhabitants in the } \\
\text { implementation of specific projects }\end{array}$ & 78.7 & 16.6 & 4.7 & 4.17 & 71.7 & 20.0 & 8.3 & 3.94 & 59.6 & 33.3 & 7.0 & 3.74 & 3.99 & 13.461 & 0.001 \\
\hline $\begin{array}{|lll|}\text { Various forms of Internet } \\
\text { communication }\end{array}$ & 71.6 & 22.5 & 5.9 & 3.98 & 68.3 & 21.4 & 10.3 & 3.87 & 61.4 & 22.8 & 15.8 & 3.68 & 3.88 & 2.880 & 0.237 \\
\hline $\begin{array}{l}\text { Participation in submitting budget } \\
\text { projects }\end{array}$ & 78.7 & 13.0 & 8.3 & 4.05 & 68.3 & 24.1 & 7.6 & 3.86 & 71.9 & 19.3 & 8.8 & 3.88 & 3.92 & 5.792 & 0.055 \\
\hline $\begin{array}{l}\text { Possibility of co-deciding on a part of } \\
\text { the public budget }\end{array}$ & 74.0 & 19.5 & 6.5 & 4.03 & 66.9 & 21.4 & 11.7 & 3.79 & 71.9 & 21.1 & 7.0 & 3.96 & 3.89 & 5.655 & 0.059 \\
\hline Joint strategy development & 81.7 & 14.2 & 4.1 & 4.17 & 71.0 & 21.4 & 7.6 & 3.90 & 68.4 & 19.3 & 12.3 & 3.77 & 3.97 & 13.290 & 0.001 \\
\hline Joint strategy implementation & 82.8 & 12.4 & 4.7 & 4.20 & 70.7 & 23.1 & 6.2 & 3.88 & 71.9 & 17.5 & 10.5 & 3.79 & 3.97 & 19.136 & 0.000 \\
\hline
\end{tabular}

Note: H - Kruskal-Wallis test, p-test probability

*-spurious relationship (the test of multiple rank comparisons did not indicate between which categories there are statistically significant differences)

Source: authors' own research. 
The evaluation was performed on a 5-point Likert scale. The highest average marks were given by the respondents to the following tools: involvement of inhabitants in the implementation of specific projects (3.99), possibility of submitting own ideas (3.97), joint strategy implementation (3.97), joint strategy development (3.97), participation in submitting budget projects (3.92), (Table 3 ).

As part of the analysis of the obtained results, the Kruskal-Wallis test was carried out, and next, if significant differences in the perception of the impact were found, the authors made a test of multiple comparisons of average ranks. The analyses were aimed at determining between which groups of respondents, depending on their level of future orientation, there appear differences in the choice of social participation tools fostering a real impact on shaping the city's development. Table 3 presents detailed results. Statistically significant differences were found for the four tools of social participation:

- joint strategy implementation $(\mathrm{p}=0.000$, $\mathrm{H}=19.136)$ - highly future-oriented respondents (average in the group at the level of 4.20) assessed the possibility of a real impact of this tool on the shaping of city development significantly higher than the medium future-oriented (3.88) and low future-oriented group (3.79);

- involvement of inhabitants in the implementation of specific projects ( $\mathrm{p}=0.001, \mathrm{H}=13.461)$ - highly future-oriented respondents (average in the group at the level of 4.17) assessed the possibility of real impact of this tool on shaping city development than medium future-oriented (3.94) and low future-oriented inhabitants (3.74);

- joint strategy development of $(\mathrm{p}=0.001$, $\mathrm{H}=13.290)$ - highly future-oriented respondents (average in the group at the level of 4.17) assessed the possibility of a real impact of this tool on shaping city development higher than medium future-oriented (3.90) and low future-oriented residents (3.77);

- possibility of submitting own ideas $(\mathrm{p}=0.005$, $\mathrm{H}=10.492)$ - highly future-oriented respondents (average in the group at the level of 4.11) assessed the possibility of real impact of this tool on shaping city development significantly higher than inhabitants with low future orientation (3.74).

The results of the analysis confirmed the second hypothesis: effective tools of social participation, according to highly future-oriented inhabitants, fostering a real impact on the city's are: involvement of inhabitants in the implementation of specific projects, joint strategy development and its joint implementation. This is confirmed by the results of the Kruskal-Wallis test, where the following results were obtained in the group of highly future-oriented residents in case of tools: involvement of inhabitants in the implementation of specific projects $\mathrm{H}=19.136$ and the average of 4.20 ; joint strategy implementation $-\mathrm{H}=13,461$ and the average of 4.17 ; joint strategy development $-\mathrm{H}=13.290$ and the average of 4.17 .

\subsection{Current and desired participation of stakeholder groups in shaping city development}

The respondents were asked about the current and desired participation of particular stakeholder groups in shaping the city's development. They stated that currently the representatives of city authorities have the largest share in shaping city development $(37.0 \%)$. This group was followed by politicians $(14.9 \%)$, inhabitants $(13.0 \%)$ and entrepreneurs $(11.0 \%)$. The respondents noticed that the participation of particular stakeholder groups in shaping the city's development in the future should be more diversified.

Table 4. Current and desired participation of particular stakeholder groups in shaping city development

\begin{tabular}{|c|c|c|c|c|c|c|c|c|c|c|}
\hline \multirow[b]{2}{*}{ Stakeholder group } & \multicolumn{4}{|c|}{ Current share (\%) } & \multicolumn{4}{|c|}{ Desired future share (\%) } & \multirow[b]{2}{*}{$\mathbf{t}$} & \multirow[b]{2}{*}{$\mathbf{p}$} \\
\hline & 想 & 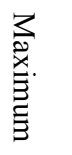 & 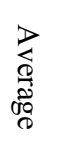 & 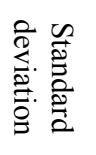 & : & 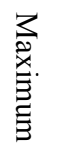 & 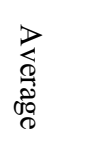 & 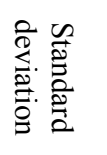 & & \\
\hline City authorities & 0 & 100 & 37.0 & 19.9 & 0 & 100 & 29.4 & 17.5 & 8.625 & 0.000 \\
\hline Inhabitants & 0 & 100 & 13.0 & 12.4 & 0 & 100 & 27.5 & 17.1 & -14.481 & 0.000 \\
\hline Entrepreneurs & 0 & 93 & 11.0 & 10.5 & 0 & 79 & 11.8 & 9.7 & -1.741 & 0.082 \\
\hline Politicians & 0 & 83 & 14.9 & 13.7 & 0 & 60 & 6.9 & 7.9 & 13.366 & 0.000 \\
\hline Scientists & 0 & 50 & 4.0 & 5.7 & 0 & 51 & 8.3 & 8.5 & -11.537 & 0.000 \\
\hline NGO representatives & 0 & 60 & 6.1 & 6.8 & 0 & 100 & 7.3 & 7.7 & -3.408 & 0.001 \\
\hline Media representatives & 0 & 55 & 5.9 & 6.8 & 0 & 40 & 4.6 & 5.9 & 4.817 & 0.000 \\
\hline Religion representatives & 0 & 93 & 8.1 & 10.7 & 0 & 65 & 4.1 & 7.5 & 7.600 & 0.000 \\
\hline
\end{tabular}

Source: authors' own research. 
In their opinion, in the future the inhabitants should have a much greater share in shaping the city's development (increase from $13 \%$ to $27.5 \%$ ). At the same time, the share of city authorities (decrease from $37 \%$ to $29.4 \%$ ) and politicians (decrease from $14.9 \%$ to $6.9 \%$ ) should be slightly lower. Next, the respondents mentioned entrepreneurs (increase from $11 \%$ to $11.8 \%$ ), scientists (increase from $4 \%$ to $8.3 \%$ ) and NGO representatives (increase from $6.1 \%$ to $7.3 \%$ ) in quite a proportional share. Detailed results are included in Table 4.

As part of the analyses, the Student's t-test was conducted for dependent samples $(t>0$ means that the share of a specific group is greater than it should be). The obtained results are mostly statistically significant since $p<0.05$. Only in the case of a group of entrepreneurs there was no statistically significant difference between the current and desired share $(\mathrm{p}=0.082)$.

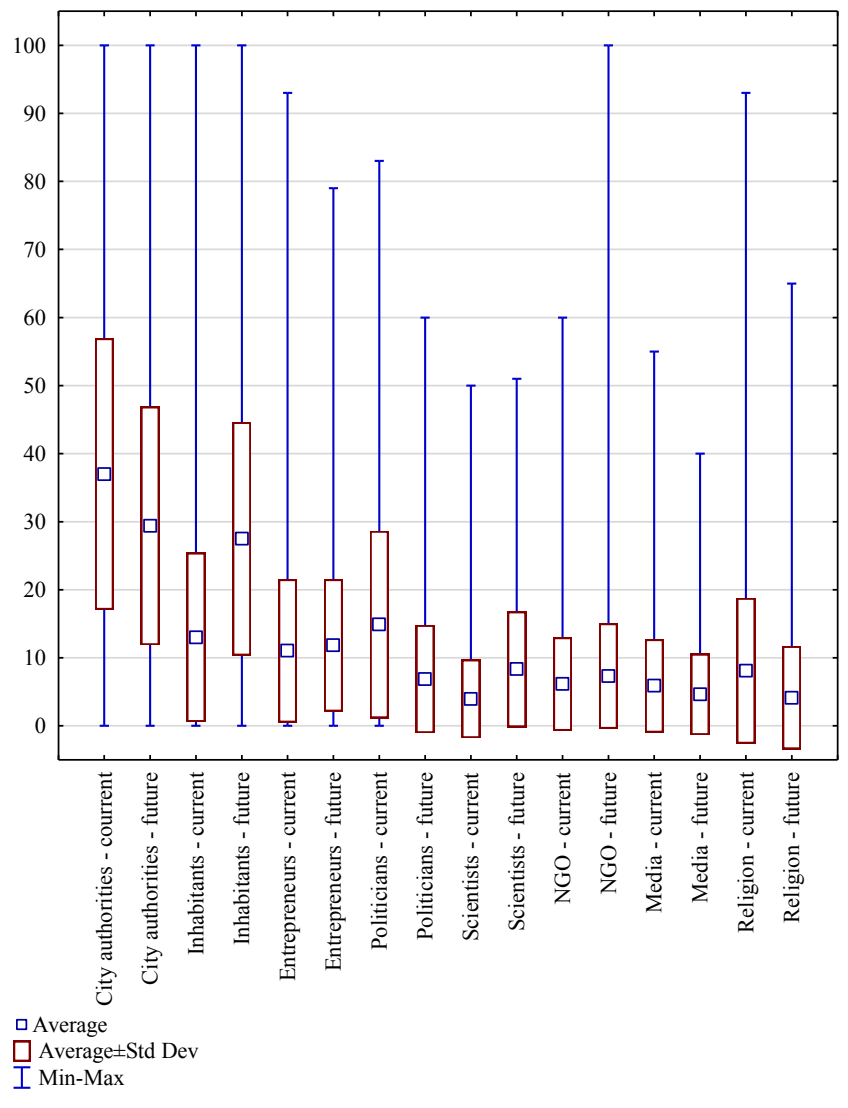

Figure 5. Current and desired participation of particular stakeholder groups in shaping city development (box plot)

Source: authors' own research.

As a result of the Student's t-test, it can be unequivocally stated that city authorities $(\mathrm{t}=8.625)$, politicians ( $\mathrm{t}=13.366)$ as well as representatives of religions $(t=7.6000)$ and the media $(t=4.817)$ have a greater share in shaping city development than they should have. In turn, inhabitants $(t=-14.481)$ and scientists $(\mathrm{t}=-11.537)$ (Table 4$)$ have much too small a share. The graphical representation of the obtained results in the form of box plots is presented in Figure 5.

Thus, the results of the analysis confirmed the third hypothesis: the current participation of inhabitants and scientists in shaping the city's development is too small compared to that of city authorities and politicians. This is confirmed by the results of the Student's t-test for dependent samples, where: city authorities $t=8.625$ and politicians $\mathrm{t}=13.366$, while inhabitants $\mathrm{t}=-14.481$, and scientists $\mathrm{t}=-11.537$.

\section{Conclusions and futures research}

The results of the research indicate that $70 \%$ of Polish inhabitants are interested in the affairs of their city. Only about $30 \%$ actively try to influence local affairs and decisions of city authorities. It should be noted that the current participation of the two social groups of inhabitants and scientists in shaping the city's development is too small in relation to the participation of city authorities and politicians. These results indicate that the respondents notice the need for more active involvement of inhabitants in the affairs of cities and the need for greater co-decision making on their future development. They see that the current management of the city, mainly by the city authorities with a strong participation of politicians, is not always adapted to the needs of the inhabitants. They therefore see the need for greater socialisation of this process through the wider involvement of ordinary inhabitants, as well as other social groups such as scientists.

Among the respondents, $70 \%$ of them were involved in at least one social activity at least once. Among the most frequently indicated were: signing petitions, participation in local government elections, voluntary work, assistance in organising a local event. The research shows that the higher the level of inhabitants' future orientation, the greater their social involvement. Highly future-oriented and medium future-oriented inhabitants more often participate in activities related to social participation in cities than low future-oriented people. Therefore, the involvement of highly and medium future-oriented inhabitants may have a positive impact on shaping the city's development due to the significant involvement in social activities demonstrated by them to date. 
According to highly future-oriented inhabitants, effective tools of social participation fostering a real impact on the city's development are: involvement of inhabitants in the implementation of specific projects, joint strategy development and its joint implementation. It should be emphasised that the tools with the highest assessment are connected with the possibility of active social involvement and at the same time enable the construction of future visions of the city's development. With the involvement of highly future-oriented inhabitants, visions may turn into effective actions, ultimately directing cities to the paths of dynamic social and economic development.

The results of the research are an attempt to integrate social participation and future orientation. They can be useful for city decision-makers who see the need for wider social involvement in the process of shaping cities' future. The results provide information to what extent and with what tools of social participation it is possible to effectively involve future-oriented stakeholders. At the same time, the results indicate what should be the participation of individual social groups in the city development process so that it is socialised and each group can articulate its needs.

The research is only the beginning of a futureoriented social participation. The presented research was conducted on a group of 516 inhabitants of Polish cities. In the next stages of the work, the authors intend to conduct research in particular social groups: city authorities and politicians, entrepreneurs, scientists and non-governmental organisations. The obtained results will be subjected to comparative analysis and then a model of futureoriented social participation will be developed. Ultimately, it will aim to improve the management of the future of cities.

Cities striving for development need strategies that will make it possible, among other things, to socialise the vision of development or to identify trends affecting its activity with social and economic conditions. These visions (strategies) can be successfully designed with the use of foresight, which gives the ability to identify changes in the micro- and macro-environment, interpret their impact on the city and formulate a strategy that will ensure long-term development. Foresight research uses a wide range of quantitative and qualitative methods of scientific and heuristic nature [50] that involve many stakeholders [51]. It is successfully applied in creating a vision of the development of countries, regions and enterprises [52-56]. In the authors' opinion, the application of foresight research in the process of managing the future of cities may be also a direction for further research. Its results will be an important contribution to the area of local unit management with the involvement of a wide range of stakeholders - representatives of various social groups.

\section{References:}

[1] Khanna, P., When cities rule the world, 2011, available online: https://www.mckinsey.com/featuredinsights/urbanization/when-cities-rule-the-world

[2] Stawasz, D., \& Sikora-Fernandez, D., Management in Polish cities in accordance with the smart city concept, Placet, Warszawa, 2015.

[3] Szymańska, D., Urbanization in the world, PWN, Warszawa, 2007.

[4] Bednarska-Olejniczak, D., Public Participation of Polish Millenials - Problems of Public Communication and Involvement in Municipal Affairs, 21st International Colloquium on Regional Sciences, Conference Proceedings, Kurdejov, Czech Republic, 2018, pp. 449-456.

[5] Comerio, M., Il community design oggi, in Spazio e società, Vol. 31/32, 1985.

[6] Davidoff, P., Advocacy and pluralism in Planning, in Campbell, S., \& Fainstein, S. (Eds.), Readings in Urban Theory, Second edition, Blackwell Publishers, UK, 2001.

[7] Friedmann, J., Planning in the Public Domain: From Knowledge to Action, New Jersey, 1987.

[8] Moatasim, F., Practice of Community Architecture: A Case Study of Zone of Opportunity Housing Co-operative, McGill University, Montreal, 2005.

[9] Carver, S., Evans, A., Kingston, R., \& Turton, I., Public participation, GIS and cyberdemocracy: evaluating online spatial decision support system, Environ. Plann. B Plann. Des., Vol. 28, No. 6, 2001, pp. 907-921.

[10] McCann, E. J., Collaborative Visioning or Urban Planning as Therapy? The Politics of Public-Private Policy Making, Prof. Geogr., Vol. 53, No. 2, 2001, pp. 207-218.

[11] Menegat, R., Participatory democracy and sustainable development: Integrated urban environmental management, Porto Alegre, Brazil. Environ. Urban., Vol. 14, 2002, pp.181-206.

[12] Buchecker, M., Hunziker, M., \& Kienast, F., Participatory landscape development: Overcoming social barriers to public involvement. Landsc. Urban Plan. Vol. 64, 2003, pp. 29-46.

[13] Allegretti, G., Paying attention to the participants' perceptions in order to trigger a virtuous 
circle, in Dias, N., (Ed.), Hope for Democracy-25 Years of Participatory Budgeting Worldwide, Loco Association, São Brás de Alportel, Portugal, 2015, pp. 47-64.

[14]Boulding, C., \& Wampler, B., Voice, Votes, and Resources: Evaluating the Effect of Participatory Democracy on Well-being, World Dev., Vol. 38, No. 1, 2010, pp. 125-135.

[15] Goodin, R. E., Dryzek, J. S., Deliberative Impacts: The Macro-Political Uptake of MiniPublics, Politics Soc., Vol. 34, 2006, pp. 219-244.

[16]Hassan, G. F., El Hefnawi, A., \& El Refaie, M., Efficiency of participation in planning, Alex. Eng. J., Vol. 50, 2011, pp. 203-212.

[17]Chado, J., \& Johar, F. B., Public Participation Efficiency in Traditional Cities of Developing Countries: A Perspective of Urban Development in Bida, Nigeria, Procedia Soc. Behav. Sci., Vol. 219, 2016, pp. 185-192.

[18]Beierle, T. C., Using Social Goals to Evaluate Public Participation in Environmental Decisions, Rev. Policy Res., Vol. 16, 1999, pp. 75-103.

[19]Callahan, K., Citizen Participation: Models and Methods, Int. J. Publ. Admin., Vol. 30, No. 11, 2007, pp. 1179-1196.

[20] Anttiroiko, A.-V., City-as-a-Platform: The Rise of Participatory Innovation Platforms in Finnish Cities, Sustainability, Vol. 8, 2016, 922.

[21] Muñoz, L. A., \& Rodríguez Bolívar, M. P., Tools Used by Citizens for Participation in European Smart Cities, Proceedings of the 19th Annual International Conference on Digital Government Research: Governance in the Data Age, Delft, Netherlands, 30 May-1 June 2018, pp. 92:1-92:2.

[22] Svobodova, L., Social Networks and Web Pages Used by Regional Municipalities in the Czech Republic, in Themistocleous, M., \& Morabito, V. (Eds.), Information Systems, Springer, Berlin, 2017, pp. 210-218.

[23] Srivastava, P., \& Mostafavi, A., Challenges and Opportunities of Crowdsourcing and Participatory Planning in Developing Infrastructure Systems of Smart Cities, Infrastructures, Vol. 3, 2018, 51.

[24] Goldfrank, B. The politics of deepening local democracy-Decentralization, party institutionalization, and participation, Comp. Politics, Vol. 39, 2007, pp. 147-168.

[25]Bednarska-Olejniczak, D., Olejniczak, J., \& Svobodová, L. Towards a Smart and Sustainable City with the Involvement of Public Participation-The Case of Wroclaw, Sustainability, Vol. 11, 2019, 332.
[26] The World Bank, Decentralization Briefing Notes, WBI Working Papers, The World Bank, Washington, 1999.

[27]Reed, M. S., Stakeholder participation for environmental management: A literature review, Biol. Conserv., Vol. 141, 2008, pp. 2417-2431.

[28] Voinov, A., \& Bousquet, F., Modelling with stakeholders, Environ. Modell. Softw., Vol. 25, 2010, pp. 1268-1281.

[29] Beierle, T. C., \& Konisky, D. M., Values, conflict, and trust in participatory environmental planning, J. Policy Anal. Manag., Vol. 19, 2000, pp. 587-602.

[30]Bifulco, F., Tregua, M., \& Amitrano, C.C., Smart Cities and Innovation: A multi-stakeholder perspective, J. Manag. Mark., Vol. 2, 2014, pp. 2733.

[31] Giffinger, R., Fertner, Ch., Kramar, H., Kalasek, R., Pichler-Milanovic N., \& Meijers E., Smart Cities. Ranking of European medium-sized cities, Vienna University of Technology, 2007.

[32] Caragliu, A., Del Bo, Ch., Nijkamp, P., Smart Cities in Europe, J. Urban Technol., Vol. 18, No. 2, 2011, pp. 65-82.

[33] Neirotti, P., De Marco, A., Cagliano, A., Mangano, G., \& Scorrano, F., Current trends in Smart Cities initiatives: Some stylised facts, Cities, Vol. 38, 2014, pp. 25-36.

[34] Lombardi, P., Giordano, S., Farouh, H., \& Yousef, W., Modelling the smart city performance, Eur. J. Soc. Sci., Vol. 25, No. 2, 2012, pp. 137-149.

[35] Tomaszewska, E., \& Florea, A., Urban smart mobility in the scientific literature - bibliometric analysis, Eng. Manag. Prod. Ser., Vol. 10, No. 2, 2018, pp. 41-56. doi: 10.2478/emj-2018-0010

[36] Winkowska, J., Szpilko, D., \& Pejic, S., Smart city concept in the light of the literature review, Eng. Manag. Prod. Ser., Vol. 11, No. 2, 2019, pp. 70-86. [37] European Union, Cities of tomorrow. Challenges, visions, ways forward, European Commission, Directorate General for Regional Policy, 2011.

[38]Fung, A., Putting the Public Back into Governance: The Challenges of Citizen Participation and Its Future, Public Adm. Rev., Vol. 75, No. 4, 2015, pp. 513-522. doi: 10.1111/puar.12361

[39]Kjaer, A., Trend Management Toolkit, A Practical Guide to the Future, Palgrave Macmillan, London, 2014.

[40]Beal, S. J., The development of future orientation: underpinnings and related constructs, Paper No. 32, 2011, available online: http://digitalcommons.unl.edu/psychdiss/32 
[41] Sciarra, D. T., \& Ambrosino, K. E., Postsecondary expectations and educational attainment, Professional School Counseling, Vol. 14, No. 3, 2011, pp. 231- 241.

[42]Robins, R. N., \& Bryan, A., Relationships between future orientation, impulsive sensation seeking, and risk behavior among adjudicated adolescents, J. Adolesc. Res., Vol. 19, No. 4, 2004, pp. 428- 445.

[43]Kuosa, T., Towards the dynamic paradigm of futures research - how to grasp a complex futures problem with multiple phases and multiple methods, Turku School of Economics, Turku, 2009.

[44] Kuosa, T., The Evolution of Strategic Foresight - Navigating Public Policy Making, Ashgate \& Gower Publishing, Farnham, 2012.

[45] Nurmi, J.-E., M. E. Poole, \& R. Seginer, Tracks and Transitions - Comparison of Adolescent Futureoriented Goals, Explorations, and Commitments in Australia, Israel, and Finland, Int. J. Psych., Vol. 30, No. 3, 1995, pp. 355-375.

[46]Luyckx, K., Goossens, L., \& Soenens, B. A Developmental Contextual Perspective on Identity Construction in Emerging Adulthood: Change Dynamics in Commitment Formation and Commitment Evaluation, Dev. Psych., Vol. 42, No. 2, 2006, pp. 366-380.

[47] Seginer, R., Future Orientation in Times of Threat and Challenge: How Resilient Adolescents Construct their Future, Int. J. Behav. Dev., Vol. 32, No. 4, 2008, pp. 272-282.

[48] Metsämuuronen, J., Basics of futures studies, in Metsämuuronen, J. (Ed.), Handbook of Basics of Research Methods in Human Sciences, Oy Internation Methelp, Helsinki, 2012, pp. 323- 381.

[49] Nazarko, J. Regional economic foresight. Methodology and research instruments, ZPWiM, Warszawa, 2013.

[50]Nazarko, J., Glinska, U., Kononiuk, A., \& Nazarko, Ł., Sectoral foresight in Poland: thematic and methodological analysis, Int. J. Foresight Innov. Policy, Vol. 9, No. 1, 2013, pp. 19-38.

[51] Szpilko, D. Foresight as a tool for the planning and implementation of visions for smart city development, Energies, Vol. 13, No. 7, 2020, 1782.

[52]Ejdys, J., Future oriented strategy for SMEs, Procedia Soc. Behav. Sci., Vol. 156, 2014, pp. 8-12. [53]Ejdys, J., \& Nazarko, Ł., Economic foresight an instrument of orientation for the future, Prace Nauk. Uni. Ekon. we Wrocławiu, Vol. 340, 2014, pp. 651-664.

[54] Chodakowska, E., \& Nazarko, J. Environmental DEA method for assessing productivity of European countries, Technol. Econ. Dev. Econ., Vol. 23, No. 4, 2017, pp. 589-607. doi: 10.3846/20294913.2016.1272069

[55] Szpilko, D., The Future of Tourism Development in the Podlaskie Voivodeship, Procedia Soc. Behav. Sci., Vol. 213, 2015, pp. 977984.

[56] Kononiuk A., Sacio-Szymańska A., \& Gáspár, J., How do companies envisage the future? Functional foresight approaches. Eng. Manag. Prod. Ser., Vol. 9, No. 4, 2017, pp. 21-33. doi: 10.1515/emj-2017-0028

\section{Creative Commons Attribution License 4.0 (Attribution 4.0 International, CC BY 4.0)}

This article is published under the terms of the Creative Commons Attribution License 4.0 https://creativecommons.org/licenses/by/4.0/deed.en_US 